\title{
顕微ラマン分光法による無機・有機複合材料の新規分析方法
}

\author{
福田和繁 · 大谷若菜 ·松本恵理子 · 川島徳道 · 高田朋典 \\ 桐蔭横浜大学医用工学部，225-8502 横浜市青葉区鉄町 1614
}

\section{Novel Analysis of Inorganic-Organic Composites using Raman Microscopy}

\author{
Kazushige FUKUDA, Wakana OHOTANI, Eriko MATHUMOTO, \\ Norimichi KAWASHIMA and Tomonori TAKATA
}

Faculty of Biomedical Engineering, Toin University of Yokohama, 1614, Kurogane-cho, Aoba-ku, Yokohama-shi 225-8502

\begin{abstract}
Recently inorganic/organic composites, such as calcium carbonate and water-soluble organic polymer with fine and complex structures have been actively advancing. Therefore, it is necessary to develop a novel analytical method for these materials. In order to solve the problem, a comprehensive non-destructive methodology for the simultaneous quantitative analysis of the calcium carbonate crystal phases in their binary mixtures and organic polymers was developed, based on the use of a Raman microscope. In this method, relative error of aragonite was on a level of $\mathrm{X}$-ray diffraction, while that of organic polymers was $30 \%$.
\end{abstract}

[Received March 16, 2006; Accepted July 20, 2006]

Key-words : Raman microscope, Calcium carbonate, Polymorphism, Quantitative analysis, Composite material, Aragonite, Calcite, $X$-ray diffraction

\section{1. 緒 言}

近年，新規無機・有機複合材料の分野に抢いて，バイオミネ ラリゼーション（生体鉱物化）が注目されている1)。例えば, アワビの貝殼はバイオミネラリゼーションにより生成したバイ オミネラルであるが，炭酸カルシウム（主成分：アラゴナイト 型）と生体高分子（タンパク質と多糖類）がナノスケールの規 則性で積層化した構造を有している。このような構造の貝殼 は，一般的な合成方法でつくられた炭酸カルシウム結晶の約 3000倍の強度を有することが知られている。そこで，バイオミ ネラリゼーションを模倣した新規無機・有機複合材料の研究が 精力的に進められている. その結果，バイオミネラリゼーショ ンを模倣したアラゴナイト型炭酸カルシウム（以下アラゴナイ ト)の合成では, 各原料成分の濃度, 温度, $\mathrm{pH}$ などのほかに, 水溶性有機高分子の存在, 更には, 結晶が析出あるいは成長す るための足場となるマトリックスの存在が重要であることが報 告されている2 2 )

生成した炭酸カルシウム結晶の微小領域内 $(\mu \mathrm{m}$ オーダー $)$ に抢ける多形とその結晶上に存在する有機高分子を定量的に知 ることは反応機構を解明するうえで重要である。しかし，従 来，結晶上の有機成分を多形と同時に分析することは困難で あった。

このため, 反応液中の水溶性高分子の経時的濃度変化を分析 するか，合成した複合材料から水溶性高分子を溶解させ定量分 析するなどの手法で水溶性高分子成分の多形への影響を推定す るか，あるいは赤外分光法で水溶性有機高分子と炭酸カルシウ 么の相互作用を定性的に解析している ${ }^{4)}$.

また，炭酸カルシウム結晶の多形に関して，Kontoyannis ら は, 顕微ラマン分光法が微小領域（空間分解能約 $1 \mu \mathrm{m}$ ) 内の 多形を検出することが可能であることに注目し，炭酸カルシウ ムの多形の定量分析法を報告している ${ }^{9)}$. 更に，Agarwal らは 水溶性有機高分子共存下で結晶化された炭酸カルシウムの多形 をIn-Situ 観察し，ラマン分光法がバイオミネラリゼーション を模倣した新規炭酸カルシウム系複合材料の研究においても有
用な分析法であることを示している(10)。 また，赤外分光法によ る炭酸カルシウムの多形の定量分析 ${ }^{11), 12)}$ も提案されているが, これらの方法は古くから使用されているX 線回折と比較して 際立った有効性がないため，バイオミネラリゼーションを模倣 した炭酸カルシウムの合成研究のための分析法として使用され た例は少ない。

以上のように，バイオミネラリゼーションを模倣した新規炭 酸カルシウム系無機・有機複合材料を創製する研究と比較し て, 得られた複合材料の分析方法の研究はかなり遅れている.

このような状況下, 従来, 顕微ラマン分光法は, 単に炭酸力 ルシウム系無機・有機複合材料の多形の定性分析あるいは定量 分析のみに使用されているにすぎなかった，そこで，本研究で は, 顕微ラマン分光法を用いて, 炭酸カルシウム系無機・有機 複合材料中の炭酸カルシウムの多形（カルサイト及びアラゴナ イトの 2 成分）々水溶性有機高分子の 3 成分を同時に，かつ簡 便に定量分析に応用する方法について検討した.

なお，炭酸カルシウム系無機・有機複合材料のモデル無機成 分にはカルサイト型炭酸カルシウム（以下カルサイト）及びア ラゴナイトを用いた。 また，水溶性有機高分子成分には，バイ オミネラリゼーションで使用された実績があるポリアクリル 酸と構造が酷似し，かつ炭酸カルシウムのスラリーに分散剤と して工業的にも広く使用され打り，炭酸カルシウムの粒子表面 に均一に吸着されると考えられるポリアクリル酸ナトリウム （NaPA）及び水溶性高分子であるが NaPA と構造が大きく異 なるポリビニルピロリドン（PVP）を用いて検討した.

\section{2. 実 験}

\section{1 試薬及び試料の調製}

カルサイト（軽質炭酸カルシウム：カルサイト $100 \%$, 粒子 径 : 長径 $1.5 \mu \mathrm{m}$, 短径 $0.4 \mu \mathrm{m}$ ) 及びアラゴナイト（アラゴナイ ト $80 \%$ ，カルサイト $20 \%$, 粒子径：長径 $1 \mu \mathrm{m}$ ，短径 $0.4 \mu \mathrm{m}$ ) は丸尾カルシウム製をそのまま使用した。なおカルサイト及び アラゴナイトは水酸化カルシウムスラリーに炭酸ガスを通気す 
ることにより製造されたものである，また，NaPA は東亜合成 製（アロン T-40：重量度600）を，PVP は和光純薬製（重合度 500）を使用した．検量線用のカルサイトーアラゴナイト系混合 試料は，計算量のカルサイト及びアラゴナイトにメタノールを 加え，よく混合してペースト状とし，ガラス板上に塗布し室温 で一晚放置し半乾燥状態とした後 $130^{\circ} \mathrm{C} て ゙ 15 \mathrm{~min}$ 乾燥した後, 乳鉢で粉砕することにより調製した．同様の操作によりカルサ イト-NaPA 系混合試料及びカルサイト-PVP 系混合試料も調 整した。ただし，これらの試料の場合は，分散媒に蒸留水を使 用した。

\section{2 顕微ラマン分光スペクトルの測定条件}

励起光源として532 $\mathrm{nm}$ の YAGレーザ, 分光器として 1800 $\mathrm{gr} / \mathrm{mm}$ のグレーティングを, 検出器として CCD を搭載した共 焦点顕微ラマン分光装置（NRS-3200型レーザラマン分光光度 計，日本分光製）を使用した。

検量線の作成において，測定スポット内で標準試料の各成分 の混合比が，標準試料の調整時の配合比であり，しかも，炭酸 カルシウムの各結晶, 粒子表面に吸着された水溶性有機高分子 の方位が十分にランダムである必要がある．この点を考慮して 測定のスポットサイズは $20 \mu \mathrm{m} \times 20 \mu \mathrm{m}$ とした。 また， 1 ポイ ント当たりの露光時間は $30 \mathrm{~s}$, 積算回数 2 回で抢こなった.な 押, 深さ方向の分解能は $30 \sim 40 \mu \mathrm{m}$ と推定される.

\section{3 定量分析に使用するピークの決定及び検量線の作成}

検量線作成に使用するピークを決定するために，カルサイ ト，アラゴナイト，NaPA 及び PVP の単独のスペクトルを測 定した．検量線に使用するピークは相互に重ならないものの中 から決定した.

アラゴナイトの検量線用標準試料は2.1節で述べた方法で力 ルサイトを基準物質として, 濃度を変えて数点作成した. また, 同様に NaPA あるいはPVP の検量線用標準試料を作成した。

検量線はカルサイトの質量に対するアラゴナイトの質量比と カルサイトの特性ピークのピーク面積に対するアラゴナイトの 特性ピークのピーク面積比との関係で作成した，また，同様の 手法で NaPA 及び PVP の検量線も作成した.

\section{4 検量線からの組成算出方法}

検量線から組成を算出する方法についてカルサイトーアラゴ ナイト-NaPA 系を例に説明する.

2.3 節で作成した検量線を用いて，カルサイトの質量に対 する各成分の質量比を求め, (1) 式〜 (3) 式で各成分の含有率 [mass\%]を算出した.

$$
\begin{aligned}
& \text { アラゴナイト }[\%]=\frac{W_{1}}{\left(W_{1}+W_{2}+1\right)} \times 100 \\
& \mathrm{NaPA}[\%]=\frac{W_{2}}{\left(W_{1}+W_{2}+1\right)} \times 100 \\
& \text { カルサイト }[\%]=\frac{1}{\left(W_{1}+W_{2}+1\right)} \times 100
\end{aligned}
$$

$W_{1}$ : 検量線から求めたカルサイトの質量に対するアラ ゴナイトの質量比

$W_{2}$ : 検量線から求めたカルサイトの質量に対する NaPAの質量比

なお，(2)式の $W_{2}$ を検量線から求めたカルサイトの質量に対 する PVP の質量比を使用することにより，カルサイトーアラゴ ナイト-PVP 系の組成分析を算出することができる.

\section{5 他の分析方法との比較}

顕微ラマン分光法による炭酸カルシウムの多形の分析結果を 従来の多形の一般的な分析法である X 線回折法で分析した結 果と比較した.

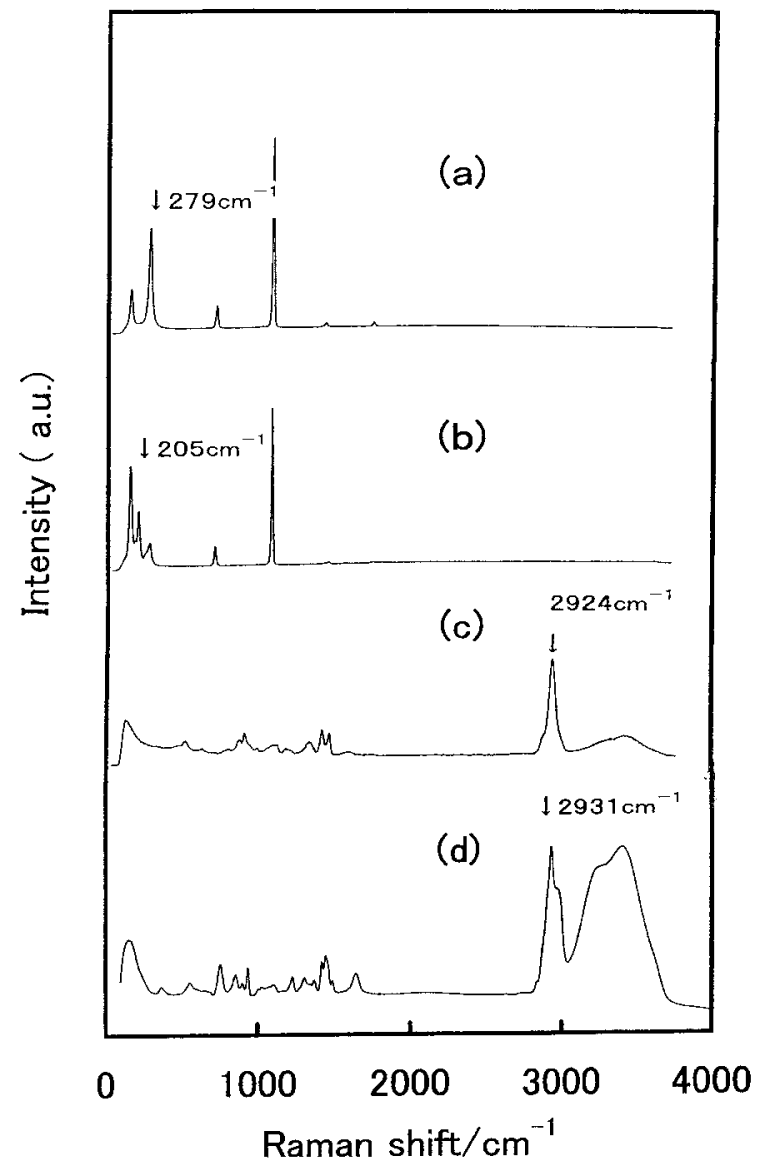

Fig. 1. Raman spectra of (a) calcite, (b) aragonite (c) NaPA and (d) PVP.

\section{3. 結果及び考察}

3.1 カルサイト，アラゴナイト，NaPA 及び PVP のラマン スペクトルと特性ピーク

カルサイト，アラゴナイト， NaPA 及び PVPのそれぞれの ラマンスペクトルを図1(a)〜 (d) に示した.

図 1 (a) はカルサイトのスペクトルであり, 強度が強い順に $1085,279,155 及 ひ ゙ 716 \mathrm{~cm}^{-1}$ 付近に特性ピークが確認された. 図 1 (b)はアラゴナイトのスペクトルであり, 同様に1085, 151, 205 及び $704 \mathrm{~cm}^{-1}$ 付近に特性ピークが確認された。 また，ここ で使用したアラゴナイトにはカルサイトが $20 \%$ 含まれているた め, $279 \mathrm{~cm}^{-1}$ にカルサイト由来のピークが認められた。図 1 (c)はNaPAのスペクトルであり，2924，1416，1465及び 905 $\mathrm{cm}^{-1}$ に特性ピークが確認された。更に, 図 $1(\mathrm{~d})$ はPVP のス ペクトルであり，2931，1452，753及び $938 \mathrm{~cm}^{-1}$ 付近に特性ピー クが確認された.

なお，NaPA 及びPVP は水溶液の状態で測定しているため, 図 1 (c) 及び (d) には3000 3700及び $160 \mathrm{~cm}^{-1}$ 付近に水に由来す るブロードで高強度のピークが存在することが確認された.

図 $1(\mathrm{a}) \sim(\mathrm{d})$ の結果から, ピーク強度が強いこと, 他の成分 のピークと重ならないこと等を考慮して検量線に使用するピー クは $279 \mathrm{~cm}^{-1}$ (カルサイト), $205 \mathrm{~cm}^{-1}$ (アラゴナイト), 2924 $\mathrm{cm}^{-1}$ (NaPA: $\left.\mathrm{CH}_{2}\right)$ 及び2931 $\mathrm{cm}^{-1}\left(\mathrm{PVP}: \mathrm{CH}_{2}\right)$ とした.

3.2 各成分を混合したときのラマンスペクトル

次に，各成分の特性ピークを利用して，それぞれの混合物に ついてスペクトルを検討した，炭酸カルシウム多形の分析とし 


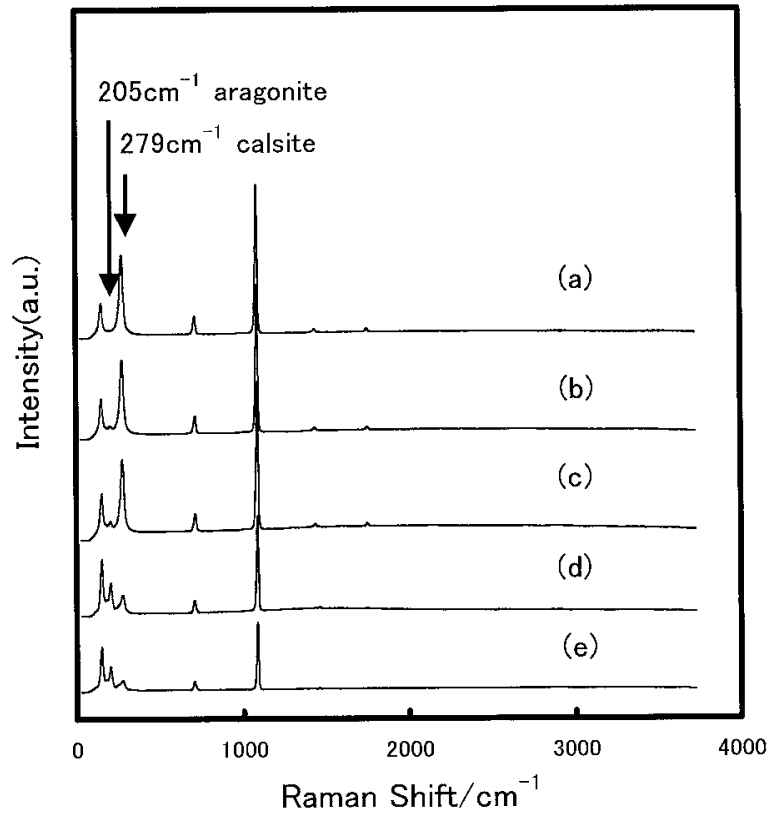

Fig. 2. Raman spectra of (a) calcite, (b) $9 \%$ aragonite- $91 \%$ calcite, (c) $18 \%$ aragonite- $82 \%$ calcite, (d) $70 \%$ aragonite- $30 \%$ calcite and (e) $80 \%$ aragonite- $20 \%$ calcite.

てカルサイトとアラゴナイトの混合物のスペクトルを図 2 に示 した. 図 2 (a) は，カルサイト $100 \%$ のきのスペクトルであ る. (b)〜 (e)はアラゴナイトとカルサイトを混合したときのス ペクトルであり，(b)，(c)，(d)，(e)はカルサイト中のアラゴナ イトの mass\%が，それぞれ 9，18，70，80\%（カルサイトに対 するアラゴナイトの質量比は $0.10,0.22 ， 2.3 ， 4.0)$ とアラゴ ナイトの混合比率を増加させたものである. その結果, (b) か ら (e)すなわち, アラゴナイトの混合比率が増加するに従っ て, アラゴナイト由来の $205 \mathrm{~cm}^{-1}$ のピーク強度が増加し, カ ルサイト由来の $279 \mathrm{~cm}^{-1}$ のピーク強度が減少していることが 確認された.

次にカルサイト中の水溶性有機高分子成分の分析としてカル サイトと NaPAの混合物について検討した。カルサイトと NaPA 混合物のスペクトルを図 3 に示した. 図 3(a) はカルサイ ト100\%のスペクトルである.（b)，(c)，（d）はカルサイト中の NaPAの mass\%が，それぞれ 1，2，4\%（カルサイトに対する

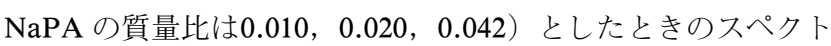
ルである. NaPA の混合比率が増加するに従い, $2924 \mathrm{~cm}^{-1}$ の ピーク強度が増加していることが確認された.

以上のことから，アラゴナイト/カルサイトの質量比と205 $\mathrm{cm}^{-1} / 279 \mathrm{~cm}^{-1}$ のピーク強度比を利用して, アラゴナイトの検 量線を作成することが可能と考えられる.

また， NaPA/カルサイトの質量比と $2924 \mathrm{~cm}^{-1} / 279 \mathrm{~cm}^{-1}$ の ピーク強度比の関係を利用して NaPAの検量線を作成すること が可能であると推定される.

更に，同様の方法で有機成分としてPVPを用いた場合につ いて検討した，その結果を図 4 に示した。図4の(a) はカルサ イト $100 \%$ のスペクトルであり，(b)，(c)，(d)，(e)はカルサイト にPVPをそれぞれ 2，3，5，10 mass\%（カルサイトに対する PVP に対する質量比 $0.020 ， 0.031 ， 0.053 ， 0.11 ）$ 添加したとき のスペクトルである．PVP の混合比率が増加するに従い, 2931 $\mathrm{cm}^{-1}$ のピーク強度が増加していることが確認された．このこ

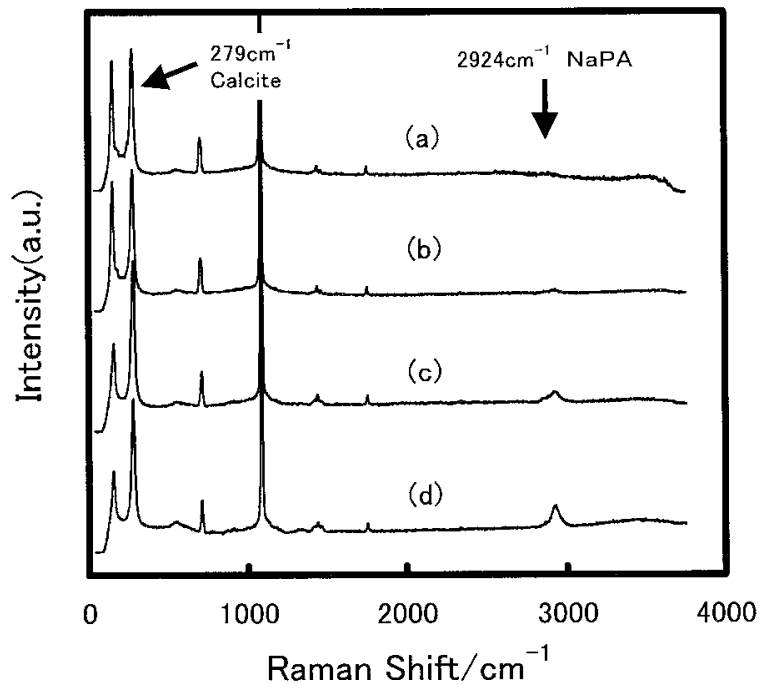

Fig. 3. Raman spectra of (a) calcite, (b) $1 \% \mathrm{NaP}-99 \%$ calcite, (c) $2 \% \mathrm{NaPA}-98 \%$ calcite and (d) $4 \% \mathrm{NaPA}-96 \%$ calcite.

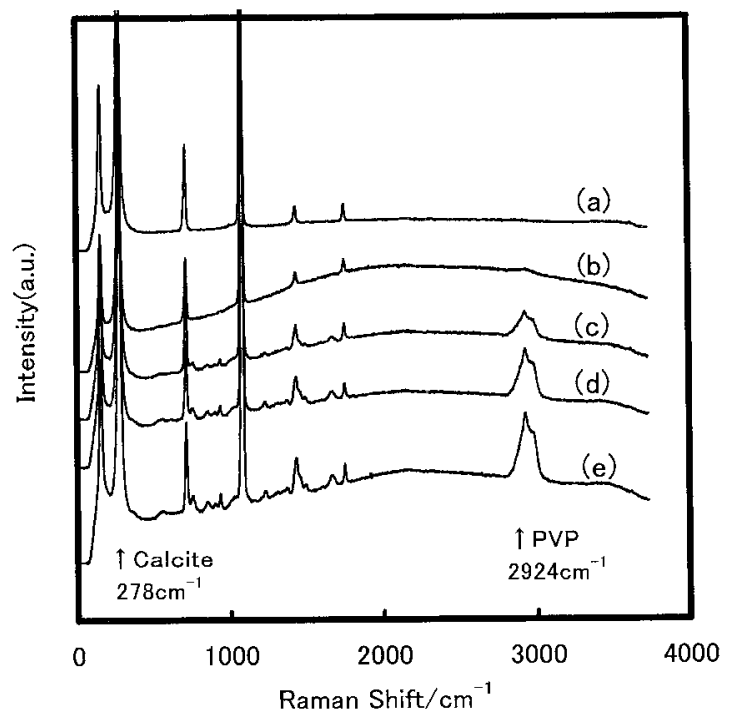

Fig. 4. Raman spectra of (a) calcite, (b) 2\%PVP-98\%calcite, (c) 3\% PVP-97\% calcite, (d) 5\% PVP-95\%calcite and (e) 10\% PVP-90\% calcite.

とにより，PVP/カルサイトの質量比と $2931 \mathrm{~cm}^{-1} / 279 \mathrm{~cm}^{-1}$ の ピーク強度比の関係を利用して PVP の検量線を作成すること が可能であると推定される.

\section{3 検量線の作成}

各混合物のスペクトルの結果から, カルサイトーアラゴナイ ト混合物中のアラゴナイト，カルサイト-NaPA 混合物中の NaPA, カルサイト-PVP 混合物中のPVPの検量線について検 討した. 図 5 はカルサイトーアラゴナイト混合物中のアラゴナ イトの検量線であり，アラゴナイト/カルサイトの質量比と205 $\mathrm{cm}^{-1} / 279 \mathrm{~cm}^{-1}$ のピーク強度（面積）比との関係をプロットし たものである. 本来は二つのピークはピーク分離処理を行うこ とが望ましいが，今回はそれぞれのピークのベースラインを想 定し面積を求めた。 また, 従来の多形の一般的な分析法である $\mathrm{X}$ 線回折法で作成したアラゴナイトの検量線（カルサイトに対 


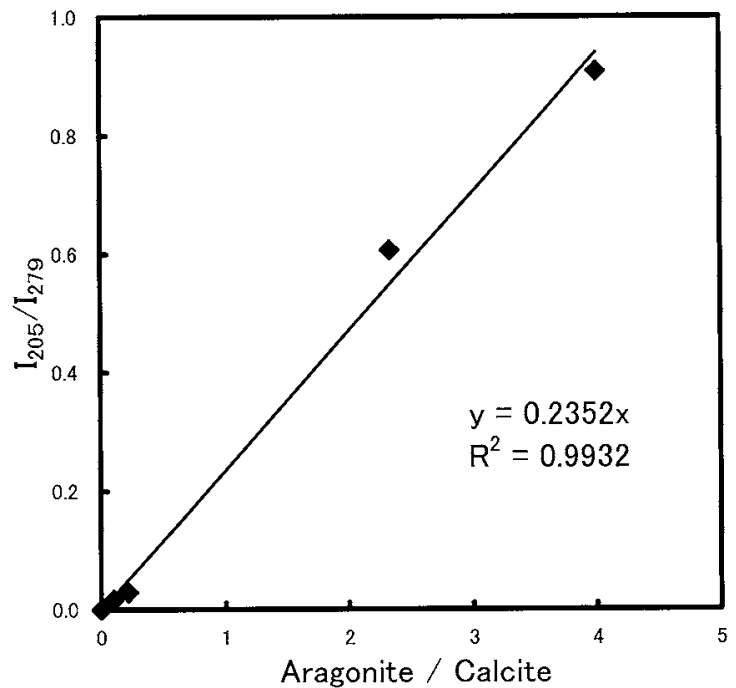

Fig. 5. Raman calibration line for aragonite-calcite mixtures.

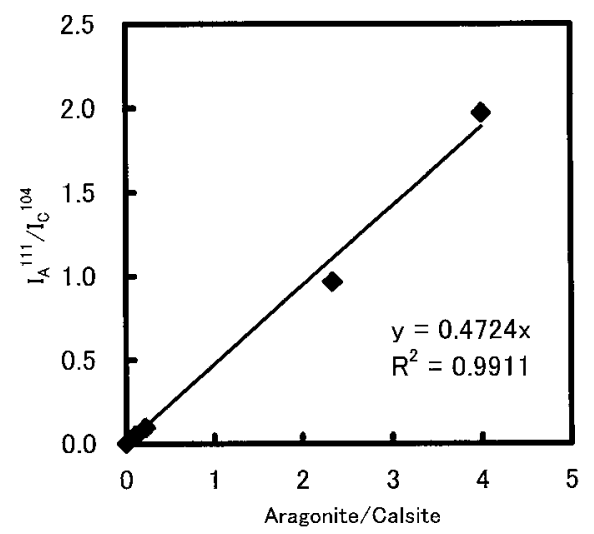

Fig. 6. XRD calibration line for aragonite-calcite mixtures.

するアラゴナイトの混合比とカルサイトの $2 \theta=29^{\circ}$ (ミラー指 数104） とアラゴナイト $2 \theta=26^{\circ}$ （ミラー指数111）の強度比々 の関係で作成）を図 6 に示した。この結果，顕微ラマン分光法 とX 線回折法の検量線の直線性を示す相関係数 $r$ は，それぞれ 0.997，0.995であり，両分析法の検量線の直線性は同等であっ た。

図 7 には，顕微ラマン分光法を用いて作成したカルサイトー NaPA 混合物中の NaPAの検量線を, 図 8 に顕微ラマン分光法 を用いて作成したカルサイト-PVP 混合物中のPVP の検量線 を示した，なお，貝殼に含まれる有機高分子成分の含有量は， 約 5\% ${ }^{7)}$ であることから，検量線の範囲は 0 万 あるいは $0 \sim 10$ $\%$ （水溶性高分子のカルサイトに対する質量比は $0 \sim 0.05$ ある

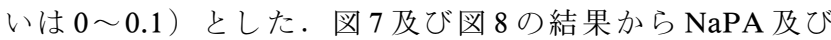
PVPの検量線の相関係数 $r$ は, それぞれ $0.999,0.979$ と直線性 が良好であることが確認された，以上のことから，顕微ラマ ン分光法を使用することにより，カルサイトーアラゴナイトー NaPA 系, カルサイトーアラゴナイト-PVP系の各混合物系に おいて，無機物及び有機物からなる 3 成分を同時に，しかも， 簡便に定量分析可能であることが確認できた。

\section{4 分析精度の確認}

カルサイトーアラゴナイト混合物（検量線用試料）中のアラ

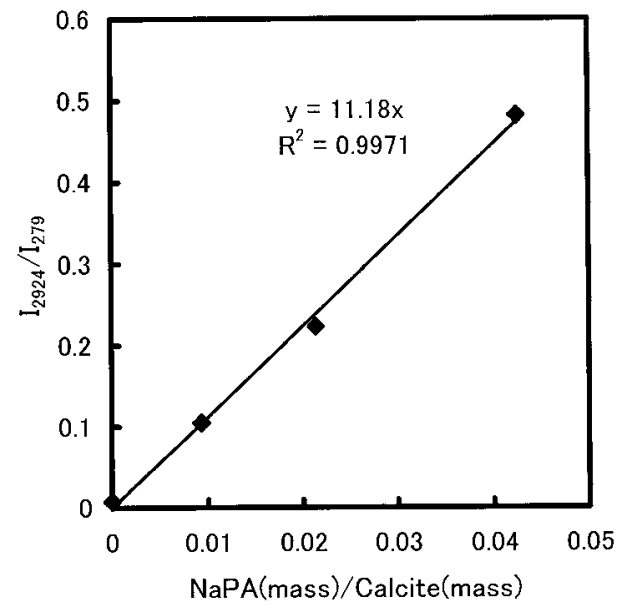

Fig. 7. Raman calibration line for NaPA-calcite mixtures.

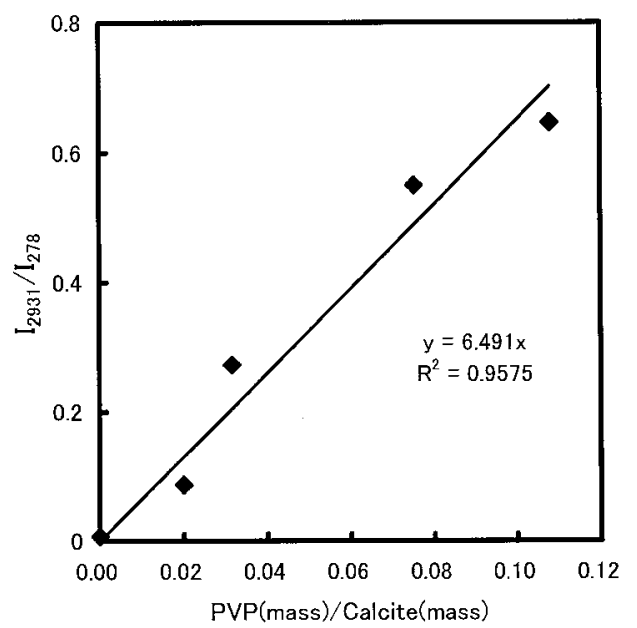

Fig. 8. Raman calibration line for PVP-calcite mixtures.

ゴナイトの含有率と顕微ラマン分光法で測定して求めた予測值 （2.3～2.4節で示した方法で求めた含有率）の関係を回帰分析し た結果, アラゴナイトの含有率と予測值の回帰直線の傾き $a$ は 0.996，相関係数 $r$ は0.996であった，比較のために，炭酸カル シウムの多形の一般的な分析方法である X 線回折法を用いて 測定した場合の回帰直線の傾き $a$ は 0.985 , 相関係数 $r$ は 0.999 であった．以上の結果から，顕微ラマン分光法は X 線回折の 分析精度とほぼ同等であることが確認された。

また，カルサイト-NaPA 混合物中の NaPA に関して同様に検 討したところ傾き $a$ は 0.999 , 相関係数 $r$ は 0.998 , カルサイトPVP 混合物中のPVPに関して $a$ は 0.998 , 相関係数 $r$ は 0.979 であった。

今回の検討結果において, 水溶性有機高分子である NaPA 及 びPVPの含有率と予測值が最も乘離したのは, PVPの含有率 $2 \%$ の試料で, 相対䛊差は $30 \%$ であった.

統計的に十分な検討はしていないが，以上の結果から顕微ラ マン分光法は微小領域内（ $\mu \mathrm{m}$ オーダー）のアラゴナイトの含 有率を X 線回折並みの分析精度で分析することが可能であり, しかも，水溶性有機高分子である NaPA 及び PVP も相対䛊差 が最大 $30 \%$ 程度で分析可能と推定されることが確認された。 


\section{4. 結 論}

バイオミネラリゼーションの手法を模倣した炭酸カルシウムー 水溶性有機高分子複合材料の合成で得られた材料の分析とし て, 従来, 微小領域内（数 $\mu \mathrm{m}$ オーダー）のカルサイト, アラ ゴナイト及び水溶性有機高分子の 3 成分を同時に定量分析する ことは不可能であった. 本研究の結果, 炭酸カルシウムの多形 の定性分析あるいは定量分析に使用されるにすぎなかった顕微 ラマン分光法を利用して, 微小領域内に打けるアラゴナイト, カルサイト，有機ポリマーの 3 成分を同時に，しかも簡便に定 量分析する手法を確立することができた.

本法を用いたアラゴナイトの分析精度は, 粉末 X 線回折法 を用いた分析方法とほぼ同等の值を示した.

また，今回，複合材料のモデル混合物として用いたカルサイ トーアラゴナイト-NaPA 系及びカルサイトーアラゴナイト-PVP 系に抢いて，水溶性有機高分子の誤差が最も大きかったのは PVP の含有量が $2 \%$ の試料で，相対誤差は $30 \%$ であった。

以上の結果より，顕微ラマン分光法を用いた本分析法はバイ オミネラリゼーションの手法を模倣した炭酸カルシウム系複合 材料の分析あるいは合成反応を解析する新しい手段としての応 用が期待できる。

\section{References}

1) Masuda, Y. and Koumoto, K., Chemistry and Education, Vol.
48, pp. 556-559 (2000) [in Japanese].

2) Sugawara, A. and Kato, T., Chem. Commun., pp. 487-488 (2000).

3) Hosoda, N., Sugawara, A. and Kato, T., Macromolecules, Vol. 36, pp. 6449-6452 (2003).

4) Yasue, T., Sato, E., Kojima, Y. and Arai, Y., J. Soc. Inorg. Mater. Japan (Muki Materiaru), Vol. 3, pp. 372-379 (1996) [in Japanese].

5) Yasue, T., Aigami, H. and Arai, Y., J. Soc. Inorg. Mater. Japan (Muki Materiaru), Vol. 5, pp. 486-492 (1998) [in Japanese].

6) Ohotani, W., Fukuda, K., Masuyama, M., Tanaka, M., Mathumoto, E. and Takata, T., Polymer Preprints, Japan, Vol. 54, No. 2, pp. 4987-4987 (2005) [in Japanese].

7) Ohotani, W., Fukuda, K., Masuyama, M., Tanaka, M., Mathumoto, E. and Takata, T., Proceedings of 14th Polymer Material Forum, pp. 64-64 (2005) [in Japanese].

8) Yasue, T., Kojima, Y. and Arai, Y., Gypsum \& Lime, No. 247, pp. 471-480 (1993) [in Japanese].

9) Kontoyannis, C. G. and Vagenas, N. V., Analyst, Vol. 125, pp. 251-255 (2000).

10) Agarwal, P. and Berglund, K. A., Crystal Growth and Design, Vol. 3, No. 6, pp. 941-946 (2003).

11) Xyla, A. G. and Koutsokos, P. G., J. Chem. Soc., Faraday Trans., Vol. 85, pp. 3165-3172 (1989).

12) Adler, H. H. and Kerr, P. F., The American Mineralogist, Vol. 47, pp. 700-717 (1962). 